\title{
Productive and reproductive performance of Dorper and its crossbreds under a Romanian semi-intensive management system
}

\author{
D. Gavojdian ${ }^{1,2}$, L.T. Cziszter ${ }^{1 \#}$, N. Pacala ${ }^{1}$ \& M. Sauer ${ }^{2}$ \\ ${ }^{1}$ Banat's University of Agricultural Sciences and Veterinary Medicine, Faculty of Animal Science and Biotechnologies, \\ Calea Aradului 119, Timisoara, 300645, Romania \\ ${ }^{2}$ Research and Development Station for Sheep and Goats of the Romanian Academy for Agricultural and Forestry \\ Sciences, Drumul Resitei km 2, Caransebes, 325400, Romania
}

(Received 29 February 2012; Accepted 1 July 2013; First published online 1 August 2013)

Copyright resides with the authors in terms of the Creative Commons Attribution 2.5 South African Licence.
See: http://creativecommons.org/licenses/by/2.5/za
Condition of use: The user may copy, distribute, transmit and adapt the work, but must recognise the authors and the South African Journal of Animal
Science.

\begin{abstract}
The overall objectives of the research were to evaluate the effect of cross-breeding Dorper (DO) rams with Turcana (TA) ewes on growth and reproductive performances of $F_{1}$ DOxTA and $R_{1}$ DOx(DOxTA) crossbred lambs reared under a semi-intensive management system; to study the adaptability of the DO breed to Romanian farming conditions; and to evaluate the effects of melatonin implants outside the breeding season on reproductive performances in DO ewes. Animals were managed on cultivated pastures, with an average stocking rate of $12 \mathrm{head} / \mathrm{ha}$. Additional $200 \mathrm{~g}$ concentrates/day were given for 90 days during the winter season and a three lambings per two years system was practised with the use melatonin implants for oestrous induction outside the natural breeding season. Dorper and $F_{1}$ crossbreds were found to be highly precocious when put to the ram as ewe lambs, with an average fertility rate of $84.2 \%$ and $79.3 \%$, respectively, compared with $19.3 \%$ in the TA controls (CG). The litter size in adult DO ewes was $136.6 \%$ versus $118.8 \%$ for the TA (CG). Dorper-sired progeny had significantly higher body weights of lambs at weaning (90 days) compared with TA purebreds $\left(23.8 \mathrm{~kg}, 23.5 \mathrm{~kg}, 21.5 \mathrm{~kg}, 19.4 \mathrm{~kg}\right.$ for DO, $\mathrm{R}_{1}, \mathrm{~F}_{1}$ and TA, respectively). At the age of 8 months, all three DO genotypes were significantly heavier $(46.1 \mathrm{~kg}, 40.7 \mathrm{~kg}$ and $43.5 \mathrm{~kg}$ for $\mathrm{DO}, \mathrm{F}_{1}$ and $\mathrm{R}_{1}$, respectively) compared with the TA females, who reached $32.3 \mathrm{~kg}$. Average daily gain from birth to 28 days of age was significantly higher in DO purebreds and $\mathrm{F}_{1}$ and $\mathrm{R}_{1}$ crossbreds compared with TA lambs (266.4 g, 253.8 g, 223.4 g and 157.3 g, respectively). Lamb survival rates until weaning were not affected by the genotype. When using melatonin implants in the DO ewes, the fertility rate increased to $88 \%$, compared with a fertility of $41.6 \%$ in non-treated DO ewes. Out-of-season prolificacy was not affected by melatonin treatment, with litter size being $127 \%$ and $120 \%$ in treated and non-treated DO ewes, respectively. The DO breed performed well under Romanian semi-intensive management, and proved to be a highly adaptable breed to the new rearing conditions.
\end{abstract}

Keywords: Sheep, heterosis, growth, fertility rates, melatonin implants

\# Corresponding author: cziszterl@animalsci-tm.ro

\section{Introduction}

Over 70\% of income obtained in the Romanian sheep breeding sector in the last five years has been from meat production, followed by milk production (with $20 \%-25 \%$ of income), with less than $5 \%$ from wool and skin production (Padeanu, 2010). With a population of 8.4 million breeding ewes (Euro Stat, 2012), Romania's sheep flock holds third place among European countries in sheep numbers, and has an annual growth rate of 3.5\% - 5\% (MADR, 2012). The Turcana (TA) breed is the most popular sheep breed in Romania, accounting for over 6 million animals, and representing roughly $70 \%$ of the national flock (Daraban et al., 2009; Ilisiu et al., 2010). Despite the breed's popularity, moderate traits for meat production such as a low litter size of 105\% - 115\% and a growth rate of 120 - $180 \mathrm{~g} /$ day (Georgescu et al., 2000; Voia, 
2005) make the breed unsustainable and unprofitable for current lamb and mutton production enterprises. In western Romania, where the experiments were carried out (Banat region), the TA breed represents over 90\% of the total sheep population, and the average flock in the Banat region is 450 - 600 head. Carcass quality is low in TA lambs. Most of these lambs are ranked in the $\mathrm{O}$ and $\mathrm{P}$ classes, according to the EUROP classification system, with an average dressing percentage of $41 \%-43 \%$. Thus, fast methods of improving mutton production in the TA breed must be considered, and research should be focused on testing crossbreeding with other exotic specialized mutton breeds.

The Dorper (DO) is generally recognized as one of the most popular mutton breeds in South Africa (Fourie et al., 2009). The DO is a hardy composite breed, developed in the 1930s, and derived from a cross between the Black-headed Persian and the Dorset Horn. Because of its superior qualities, the South African indigenous DO breed has gained popularity in certain European countries (e.g. Austria, Hungary, United Kingdom and Switzerland). The DO is regarded as an early-maturing breed, and well-managed ewes can lamb at the age of 13 - 15 months. The average litter size of the adult DO ewe ranges from 145\% to 160\%, reaching $180 \%$ under well-managed conditions. Dorper lambs gain on average from 240 to $280 \mathrm{~g}$ per day under vastly different environmental conditions, with dressing percentages of approximately $50 \%$ (Cloete et al., 2000). At the age of 110 - 120 days, lambs can achieve a weight of $36 \mathrm{~kg}$, with adult DO rams weighing $100-120 \mathrm{~kg}$, and adult ewes weighing $60-80 \mathrm{~kg}$. Dorper sheep are generally less-selective grazers, utilizing shrubs and bushes to a greater extent - and consuming a larger number of plant species and less herbage per metabolic body size, compared with other breeds (Brand, 2000). Dorper rams can be used as terminal sires to produce lambs with high growth rates, better post-weaning feed efficiency, and superior carcass traits, similar to those of Suffolk-sired lambs (Snowder \& Duckett, 2003).

Recently, the DO breed was imported into Romania and a pilot study was initiated at the Research and Development Station for Sheep and Goats in Caransebes to evaluate it as a potential easy-care, hair breed and/or terminal meat sire. The first DO imports to Romania took place in the autumn of 2007, when eight stud animals (two rams and six unrelated pregnant ewes) were purchased from Switzerland, followed soon afterwards by other imports, especially from Austria and Germany. Because of Romanian breeders' interest in the DO sheep, in 2010 the Romanian herdbook for the breed was established, along with a genetic improvement programme. Because the number of DO purebreds is still low, an enhancement of the reproduction rate is desirable, leading to an increase of the number of animals in the herdbook. Currently, under semi-intensive rearing conditions, Romanian farmers use melatonin implants to induce oestrous outside the normal breeding season, producing three lamb crops in two years.

The overall objectives of the research were to evaluate the effect of cross-breeding Dorper (DO) rams with Turcana (TA) ewes on the growth and reproductive performances of $F_{1}$ DOxTA and $\mathrm{R}_{1}$ DOx(DOxTA) crossbred lambs reared under a semi-intensive management system; to study the adaptability of the DO breed to Romanian farming conditions; and to evaluate the effects of melatonin implants outside the breeding season on reproductive performances in DO ewes.

\section{Materials and Methods}

A two-year research project was conducted at the R\&D Station, starting in autumn 2010. Three distinct studies took place. The first study focused on the performance of mature and yearling females with the genotypes DO, TA and $\mathrm{F}_{1}$ from the autumn of 2010 to the winter of 2011. The second set of experiments was aimed at growth performance and survival rate of the four genotypes resulting from the first study, namely DO, TA, $F_{1}$ and $R_{1}$. The third set of experiments intended to evaluate the effects of melatonin implants on reproductive performances outside the breeding season in adult DO and TA ewes, starting in spring 2011. General experimental conditions are presented in Table 1.

In the first experiment, the reproductive performance of the three genotypes was evaluated during this study. The genotypes were the purebred DO ewes (imported and born in the R\&D Station, with starting year 2008, $n=56)$, the $F_{1}$ Dorper $x$ Turcana primiparous ewes $(n=33)$, which were mated with unrelated purebred DO rams, in order to produce the reciprocal-cross $\mathrm{R}_{1}$ Dorper $\mathrm{x}$ (Dorper $\mathrm{x}$ Turcana); and the purebred Turcana (TA) ewes $(n=93)$, representing the control group (CG). Females were put to the ram ( $\mathrm{n}=6$; $4 \mathrm{DO}$ rams and $2 \mathrm{TA}$ rams) starting in early September (autumn), according to the experimental design, for a period of three consecutive oestrous cycles (55 days). One measure of body weight was taken 
for the ewes just before they were put to ram. After this period, all females, irrespective of genotype, were mated with purebred TA rams (flushers).

In the second experiment, growth performance and survivability rates were evaluated of lambs belonging to the four genotypes ( $D O, n=43$; TA, $n=37 ; F_{1}, n=39$ and $R_{1} n=31$ ). Lambs were weighed at birth, 28 days and 90 days of age. Ewes were also weighed at eight months, before being put to the ram as maiden lambs. Body weight was measured with the electronic Inscale Platform Scale EOE $150 \mathrm{~K} 100 \mathrm{XL}$ equipped with an animal weighing programme, in the morning at the same hour each day, in order to obtain the highest accurate data.

Table 1 Data regarding management conditions during the trials

\begin{tabular}{llll}
\hline Location & $45.25^{\circ} \mathrm{N} / 22.13^{\circ} \mathrm{E}$ & Indoor housing & 90 days/year \\
Altitude of site & $280 \mathrm{~m}$ & Weaning of lambs & 90 days \\
Average rainfall & $737.2 \mathrm{~mm}$ & $\begin{array}{l}\text { Lambs supplementary feeding } \\
\text { Differentiated of twinning }\end{array}$ & $+100 \mathrm{~g} / \mathrm{head}$ \\
Average temperature & $20.1 /-0.8^{\circ} \mathrm{C}$ & $\begin{array}{l}\text { Cwes } \\
\text { Concentrates in winter }\end{array}$ & $200-250 \mathrm{~g} /$ day \\
Pasture type & Cultivated & Age at first mating & $8-9$ months \\
Pasture management & Rotational grazing & Reproduction season & September/October \\
Stocking rate & $12-14$ heads/hectare & & \\
\hline
\end{tabular}

In the third experiment, the effect of melatonin implants on reproductive performances of adult DO (n $=51)$ and TA $(n=60)$ ewes outside the breeding season was assessed. The evaluations were initiated in late April 2011 (spring), when ewes from the experimental groups were treated with subcutaneous $18 \mathrm{mg}$ melatonin implants, 35 days before being put to the ram. For better sperm production and enhancement of libido, DO rams $(n=4)$ received three subcutaneous implants on the same day as the females, in the periauricular area.

All ewes, regardless of genotype, were included in the research, and were reared under identical semiintensive management conditions. They were housed indoors for 90 days, without access to grazing, because of the high altitude and aggressive winter periods. Lambs were allowed to suckle their dams from birth until weaning at three months. Supplementary feeding was provided ad libitum to all lambs until weaning - a lamb-starter pelleted diet with 170 crude protein $/ \mathrm{kg}$. Figure 1 presents the Turcana and Dorper breeds as well as a $F_{1}$ crossbred maiden ewe included in the experiments.

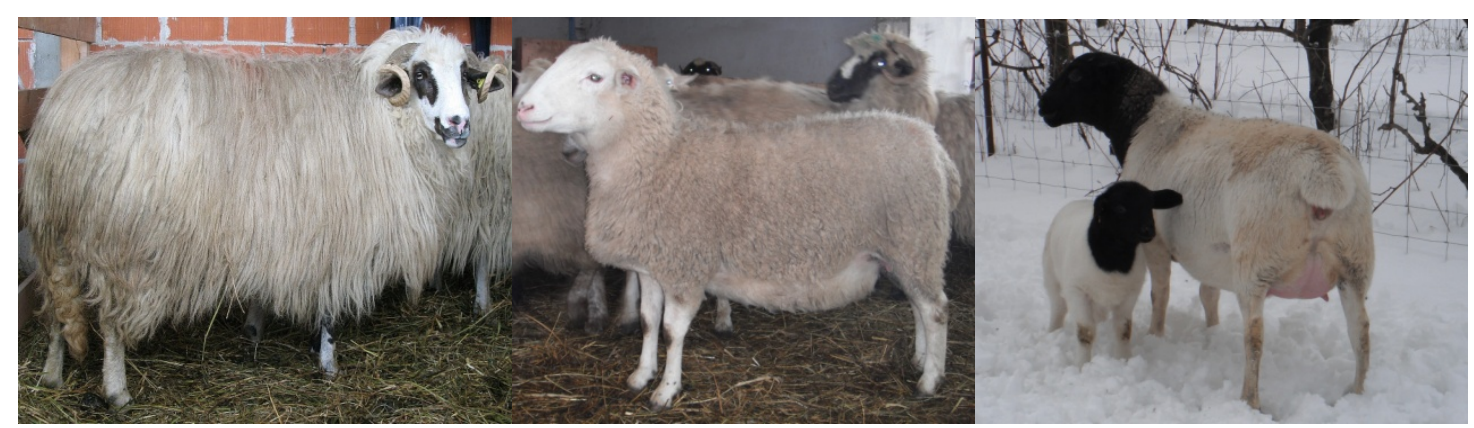

Figure 1 Turcana ewe (left), $\mathrm{F}_{1}$ Dorper x Turcana ewe (centre) and Dorper ewe with lamb (right)

Rotational grazing was practised during the experiments. The ewes were kept on a cultivated pasture with this structure: $40 \%$ legumes Trifolium repens, Trifolium pratense, Lotus corniculatus and 60\% grasses Dactylis glomerata, Lolium perene, Festuca rubra. The average stocking rate was 12 - 14 head/ha. The grazing season started in early March (spring) and ended late November (autumn). Animals had free access 
to a medium-quality lucerne hay, water and shade. Electric fencing was used for grazing management. During indoor housing, the ewes received high-quality lucerne and ryegrass hays ad libitum, as well as $200 \mathrm{~g}$ concentrate/head, with an additional $100 \mathrm{~g}$ for ewes with multiples. The transition period from indoor housing to outdoor grazing was done gradually, over an eight-day period.

Nutritional flushing was practised at the R\&D Station for three weeks before each of the two mating seasons. The ram/ewe ratio was approximately $1: 30$, in all the experimental regimens.

The R\&D station's flock is included in the National Sheep Improvement Programme, coordinated by the Romanian National Agency for Genetic Improvement and Reproduction in Animal Husbandry.

For the first experiment, these indices were considered: body weight of the ewes (kg), fertility rate (\%), litter size (\%), and litter weight gain at 28 days of age (kg). Fertility (conception rate) was calculated as the ratio between the number of ewes lambing relative to the total number of the ewes exposed to the ram. Litter size (prolificacy) was computed as the ratio between the number of lambs obtained relative to the number of ewes lambing. Litter weight gain at 28 days of age was calculated by subtracting the litter weight at birth from the litter weight at 28 days. A model for the analysis of variance was implemented, taking into consideration the age of the dam (adult or yearling) and the genotype (DO, TA for adult ewes and DO, TA, and F1 for yearling ewes). The equation for statistical analysis was:

$$
y_{i j k}=\mu+a g e_{i}+g_{j}+e_{i j k}
$$

where $y_{i j k}$ is the studied trait; $\mu$ is the overall mean; $a g e_{i}$ represents the effect of the dam's age at two levels: adult and yearling; $g_{j}$ represents the effect of the genotype with two levels for the adult ewes (DO and TA) and three levels for yearlings (DO, TA and F1); and $e_{i j k}$ is the residual effect.

In the second experiment, body weights of the lambs were recorded at birth, 28 days and 90 days, as well as at 8 months for ewe lambs. Also, the average daily gain (ADG) was calculated from birth to 28 days of age, from 28 to 90 days of age, and from birth to 90 days of age. Survivability of lambs at weaning ( 90 days of age) was also calculated. All these traits were computed for the four genotypes: DO, TA, F1 and R1. Differences between the four genotypes regarding body weight and average daily gain were studied using the $t$-test.

Outside the breeding season, reproduction indices (fertility and litter size) of two genotypes (DO and TA) under the influence of melatonin treatment were studied in the third experiment. In order to quantify the effects of the two factors, genotype and melatonin treatment, the following statistical model was used:

$$
y_{i j k}=\mu+m_{i}+g_{j}+e_{i j k}
$$

where $y_{i j k}$ is the studied trait fertility or litter size; $\mu$ is the overall mean; $m_{i}$ represents the effect of melatonin treatment at two levels: treated and non-treated; $g_{j}$ represents the effect of the genotype with two levels (DO and TA); and $e_{i j k}$ is the residual effect.

\section{Results and Discussion}

Body weight of the DO, TA adult ewes (age $\geq 2$ years) and DO, TA and $\mathrm{F}_{1}$ yearlings is set out in Table 2. Adult ewes included in the current trial were heavier than those reported by researchers in South Africa, with the average weight for the Romanian DO being $82.7 \mathrm{~kg}$. This adult weight was significantly higher than the adult weight of the TA ewes $(53.8 \mathrm{~kg} ; P<0.001)$. According to data in the literature, the DO is a medium-sized breed, with adult ewe weights ranging between 52 and $74 \mathrm{~kg}$ in native South Africa (De Waal \& Combrinck, 2000; Schoeman, 2000; Snyman \& Herselman, 2005).

The yearling DO ewes born at the R\&D Station reached an average weight of $55.0 \mathrm{~kg}$ at 18 months of age, which was significantly higher that of TA yearling $(44.0 \mathrm{~kg}, P<0.001)$ weight. As expected, $\mathrm{F}_{1}$ crossbreds had an intermediary weight of $50.0 \mathrm{~kg}$, which differed significantly from the weight of both the purebreds (DO and TA). It may be concluded that the genotype significantly influenced $(P<0.001)$ the body weight of both the yearling and adult ewes. The body weight of adult and yearling TA ewes was in agreement with values reported by other researchers (Voia, 2005; Gavojdian et al., 2010; Padeanu, 2010).

In the adult ewes, fertility was not influenced by genotype, with fertility rates being similar between the two breeds. As was expected, the TA ewes achieved slightly higher fertility rates (on average 94.6\%), 
while in adult DO ewes, the average fertility rate recorded was $93.7 \%(P>0.05)$. Fertility rates may indicate that the DO breed, although newly introduced in Romania, has adapted well to the specific housing and feeding conditions, and is able to perform well under these conditions.

Breeding ewe lambs is one approach to increasing lamb production (Gaskins et al., 2005). Ewes bred as lambs have a higher lifetime production rate than those bred as yearlings (Baker et al., 1978). In the yearling ewes, when put to ram at the age of 8 - 10 months, the fertility rates recorded were $84.2 \%, 19.3 \%$ and $79.3 \%$ for DO, TA and $\mathrm{F}_{1}$ crossbreds, respectively. Dorper and $\mathrm{F}_{1}$ genotypes had similar fertility rates, with differences between the two groups being statistically non-significant $(P>0.05)$. However, differences between TA and the two other genotypes were statistically significant $(P<0.001)$. As expected, less than one third of the ewe lambs put to ram gave birth, results that are in accordance with those published by Padeanu (2011) and Sauer et al. (2011), who reported fertility rates lower than 15\% in Turcana females when put to the ram at the age of 8 months.

The litter size in adult ewes was on average $136.6 \%$ for DO ewes and $118.8 \%$ for TA ewes. Differences between the two breeds were not significant $(P>0.05)$. For the yearling ewes, genotype did not play an important role in litter size $(P>0.05)$. The $\mathrm{F}_{1}$ crossbred yearlings produced the highest litter sizes (126.0\%), compared with $118.7 \%$ in the DO ewes and $116.6 \%$ in the TA females. This may be because the $\mathrm{F}_{1}$ females inherited higher prolificacy from the Dorper breed, and resistance and adaptation to the Romanian sheep farming practices from the TA, to which the heterosis effect is added.

Table 2 Mean ( \pm SEM) body weight and reproduction performance of adult and yearling ewes during the natural breeding season

\begin{tabular}{lccccc}
\hline Genotype & $\mathrm{n}$ & $\begin{array}{c}\text { Weight } \\
(\mathrm{kg})\end{array}$ & $\begin{array}{c}\text { Fertility } \\
(\%)\end{array}$ & $\begin{array}{c}\text { Litter size } \\
(\%)\end{array}$ & $\begin{array}{c}\text { Litter gain at 28 days } \\
(\mathrm{kg})\end{array}$ \\
\hline Dorper adult ewes ( $>$ 2 years) & 32 & $82.7^{\mathrm{a}} \pm 0.87$ & $93.7^{\mathrm{a}} \pm 4.13$ & $136.6^{\mathrm{a}} \pm 8.38$ & $7.8^{\mathrm{a}} \pm 0.16$ \\
Turcana adult ewes ( $>2$ years) & 56 & $53.8^{\mathrm{b}} \pm 0.65$ & $94.6^{\mathrm{a}} \pm 3.12$ & $118.8^{\mathrm{a}} \pm 6.30$ & $4.4^{\mathrm{b}} \pm 0.16$ \\
Dorper yearlings & 19 & $55.0^{\mathrm{c}} \pm 0.89$ & $84.2^{\mathrm{a}} \pm 9.16$ & $118.7^{\mathrm{a}} \pm 10.70$ & $6.5^{\mathrm{c}} \pm 0.16$ \\
Turcana yearlings & 31 & $44.0^{\mathrm{d}} \pm 0.70$ & $19.3^{\mathrm{b}} \pm 7.17$ & $116.6^{\mathrm{a}} \pm 17.48$ & $4.3^{\mathrm{b}} \pm 0.24$ \\
$F_{1}$ DO x TA yearlings & 29 & $50.0^{\mathrm{e}} \pm 0.72$ & $79.3^{\mathrm{a}} \pm 7.41$ & $126.0^{\mathrm{a}} \pm 8.93$ & $5.4^{\mathrm{d}} \pm 0.11$ \\
\end{tabular}

a,b,c,d,e Column means with different superscripts differ significantly at $P \leq 0.05$.

Litter weight gain at the age of 28 days is an important trait for sheep reared for meat production. Genotype played a major role in the expression of this trait, with differences between the three groups being statistically significant $(P<0.001)$. The highest litter gain was obtained in adult DO ewes $(7.89 \mathrm{~kg})$, followed by the DO yearlings $(6.55 \mathrm{~kg})$. There was no significant difference in the litter gain between adult and yearling TA ewes (4.45 vs. $4.43 \mathrm{~kg}, P>0.05$ ). As expected, $\mathrm{F}_{1}$ DOxTA crossbred lambs obtained from the yearling ewes recorded intermediary weight gain during the first 28 days of their life $(5.41 \mathrm{~kg})$, but with a significant difference $(P<0.001)$ when compared with the two parental breeds $(6.55 \mathrm{~kg}$ for the DO and 4.33 $\mathrm{kg}$ for the TA).

Data regarding body weight of the lambs at birth, 28 days and 90 days of age are set out in Table 3. The body weight of female lambs at the age of 8 months, when the females were put to ram for the first time, is shown in Table 3.

The TA breed is a dual-purpose breed, also being reared for milk production in the traditional management system. Lambs are weaned and marketed at 60 - 90 days of age. In the subsequent 3 - 4 months of lactation, ewes are milked. Therefore, the lamb weight at 60 days and 90 days of age is an important trait for their market value and for the possibility of weaning them earlier, thus maximizing the milk production of their dams. Cloete et al. (2000) stated that in South Africa DO lambs are usually slaughtered at $32 \mathrm{~kg}$ to $35 \mathrm{~kg}$ to avoid excessive body fat.

Moreover, the Romanian market demands high quantities of lambs at Easter. The demand is thus highest in April, while the normal lambing season in western Romania is January-February, depending on 
the time of Easter celebrations. Thus, a rapid growth is desirable, so that the lambs can be marketed at Easter, and ewes milked afterwards (the purebred TA), or put to ram in order to have three lambings in two years (purebred DO ewes or their crossbreds).

Table 3 Mean $( \pm$ SEM) body weight $(\mathrm{kg})$ of lambs according to genotype at $0,28,90$ days of age and at 8 months of age in female lambs

\begin{tabular}{lcccccc}
\hline Genotype & $\mathrm{n}$ & $\begin{array}{c}\text { Birth } \\
\text { weight }\end{array}$ & 28 days weight & 90 days weight & $\mathrm{n}$ & $\begin{array}{c}\text { Weight at } 8 \\
\text { months of age for } \\
\text { female lambs }\end{array}$ \\
\hline Dorper & 43 & $4.0^{\mathrm{a}} \pm 0.08$ & $11.5^{\mathrm{a}} \pm 0.14$ & $23.8^{\mathrm{a}} \pm 0.19$ & 24 & $46.1^{\mathrm{a}} \pm 0.48$ \\
Turcana & 37 & $3.5^{\mathrm{b}} \pm 0.08$ & $7.9^{\mathrm{b}} \pm 0.08$ & $19.4^{\mathrm{b}} \pm 0.16$ & 19 & $32.3^{\mathrm{b}} \pm 0.47$ \\
F $_{1}$ DOxTA & 39 & $3.5^{\mathrm{bc}} \pm 0.06$ & $9.8^{\mathrm{c}} \pm 0.12$ & $21.5^{\mathrm{c}} \pm 0.19$ & 21 & $40.7^{\mathrm{c}} \pm 0.54$ \\
$\mathrm{R}_{1}$ DOx(DOXTA) & 31 & $3.7^{\mathrm{bd}} \pm 0.07$ & $10.8^{\mathrm{d}} \pm 0.15$ & $23.5^{\mathrm{a}} \pm 0.20$ & 13 & $43.5^{\mathrm{d}} \pm 0.77$ \\
\hline
\end{tabular}

a,b,c,d Column means with the different superscripts differ significantly at $P \leq 0.05$.

The DO lambs born during the trial period had an average birth weight of $4.09 \mathrm{~kg}$, which is higher ( $P$ $<0.001)$ than the birth weight of the purebred TA lambs $(3.58 \mathrm{~kg})$. The birth weight of the $\mathrm{F}_{1}$ and $\mathrm{R}_{1}$ lambs was $3.5 \mathrm{~kg}$ and $3.7 \mathrm{~kg}$, respectively. Present results are contrary to those reported by Notter et al. (2004), who stated that DO-sired lambs tended to be lighter at birth.

Body weight at the age of 28 days was significantly affected by genotype $(P<0.001)$. These differences between the $\mathrm{DO}$ and $\mathrm{R}_{1}$ reciprocal-cross lambs were slightly less dramatic $(P<0.01)$ - possibly owing to the high gene input of the DO breed in the $\mathrm{R}_{1}$ lambs (75\%) and because the dams of the reciprocalcross lambs were hybrids themselves. The results could be explained by the genetic improvement schemes of the two purebreds. Thus, while the TA breed had been selected for resistance and coarse-wool production for many generations (Daraban et al., 2011), the DO was selected for producing fast-growing lambs (Milne, 2000).

At weaning, the weight of the lambs was influenced by genotype $(P<0.001)$, except for the differences between the $\mathrm{DO}$ and $\mathrm{R}_{1}(23.8 \mathrm{vs}$. $23.55 \mathrm{~kg}, P>0.05)$. The $\mathrm{DO}$ lambs were weaned at $23.8 \mathrm{~kg}$, and were $4.3 \mathrm{~kg}$ heavier $(P<0.001)$ than the purebred TA lambs, which had an average weight of $19.4 \mathrm{~kg}$. Growth performance of the $F_{1}$ crossbred lambs was intermediate between the two parental breeds, being on average $21.5 \mathrm{~kg}$ significantly lighter than the purebred DO and TA lambs $(P<0.001)$. These results are in accordance with those presented by Schoeman (2000), who reported that when Dorper and Merino breeds are crossed, at the age of 12 and 18 months, their progeny were approximate 5\% - 7\% heavier than midparent value, indicating the contribution of heterosis effect. A clear complementarity exists between the DO and TA breeds, which should be exploited in the near future by Romanian sheep farmers. Also, $\mathrm{R}_{1}$ DOxTA reciprocal-crosses were proven to have high growth rates, a potential that could be used to establish a synthetic population that could help improve meat production in Romanian sheep farms.

At the age of 8 months, when the ewe lambs were mated, the DO females recorded a weight of 46.1 $\mathrm{kg}$, significantly higher than the purebred TA and $\mathrm{F}_{1}$ crossbreds (32.3 $\mathrm{kg}$ and $40.7 \mathrm{~kg}$, respectively; $P$ $<0.001)$. This is similar to the weight of the $\mathrm{R}_{1}$ ewe lambs $(43.5 \mathrm{~kg}, P<0.01)$. This trait is important because of the correlation between the reproduction performance and body weight, especially fertility. Generally, in Romanian sheep farming systems, ewes are not considered suitable for reproduction until they reach a body weight of $35 \mathrm{~kg}$ in indigenous breeds. This weight is regarded as the lowest weight that will not negatively affect development of the ewe and her progeny (Pacala, 1998). Clearly, a minimum body weight should be reconsidered for DO and DO-sired females, according to the management system, and especially for the feeding strategy applied on the farm. The DO is a much heavier breed than the native TA (Table 2). Most of the ram lambs are sold to perform on other commercial sheep farms or are taken to the slaughterhouse soon after weaning, with only replacement ram lambs being kept. Therefore, the ram weight at the age of 8 months could not be recorded because of the small number of animals (three male lambs). 
The ADG for the three genotypes during the periods 0 - 28 days, 28 - 90 days and birth - 90 days is presented in Table 4. Lamb survival rates from birth until weaning (90 days) are also set out in Table 4.

Table 4 Mean $( \pm$ SEM) average daily gain (ADG) (g/day) and survival rate (\%) of lambs

\begin{tabular}{lccccc}
\hline Genotype & $\mathrm{n}$ & Birth - 28 days & $28-90$ days & Birth - 90 days & $\begin{array}{c}\text { Lamb survival 0 - 90 } \\
\text { days (\%) }\end{array}$ \\
\hline Dorper & 40 & $266.4^{\mathrm{a}} \pm 6.16$ & $197.6^{\mathrm{ac}} \pm 3.89$ & $219.0^{\mathrm{a}} \pm 2.43$ & $93.4^{\mathrm{a}} \pm 3.68$ \\
Turcana & 33 & $157.3^{\mathrm{b}} \pm 4.33$ & $185.2^{\mathrm{b}} \pm 3.01$ & $176.5^{\mathrm{b}} \pm 1.77$ & $90.2^{\mathrm{a}} \pm 4.69$ \\
$\mathrm{~F}_{1}$ DOxTA & 35 & $223.4^{\mathrm{c}} \pm 5.00$ & $188.9^{\mathrm{ab}} \pm 3.71$ & $199.6^{\mathrm{c}} \pm 2.28$ & $90.6^{\mathrm{a}} \pm 4.48$ \\
$\mathrm{R}_{1}$ DOx(DOXTA) & 29 & $253.8^{\mathrm{a}} \pm 6.15$ & $204.3^{\mathrm{c}} \pm 4.25$ & $219.7^{\mathrm{a}} \pm 2.47$ & $91.1^{\mathrm{a}} \pm 4.93$
\end{tabular}

${ }^{\mathrm{a}, \mathrm{b}, \mathrm{c}}$ Column means with the different superscripts differ significantly at $P \leq 0.05$.

The ADG values from birth to 28 days of age were influenced mostly by the dam, because during this period the lamb/lambs are consuming mainly milk, and little of the weight gain is owing to additional feed. Thus mothering ability is important during the first three to four weeks of development of the new-born lamb/lambs (Ramsey et al., 1994). Genotype played a significant role $(P<0.001)$ in the ADG, except for the differences between the $\mathrm{DO}$ and $\mathrm{R}_{1}$ reciprocal-cross lambs, which achieved similar growth rates (266.4 g/day and $253.8 \mathrm{~g}$ /day, respectively). Similar results for the ADG during first 28 days of life of Turcana and $\mathrm{F}_{1}$ German Blackheaded Mutton x Turcana crossbred lambs were recorded by Gavojdian et al. (2011), with 194 $\mathrm{g} /$ day being noted in purebred Turcana lambs and $229.4 \mathrm{~g}$ /day in crossbred lambs.

The ADG values were lower during the 28 - 90 day period, and the effect of genotype also decreased. There was similar growth performance for the DO and $\mathrm{R}_{1}$ lambs (197.6 g and $204.3 \mathrm{~g}$, respectively) ( $P$ $>0.05$ ). These values were comparable with those recorded by Nkosi \& Meeske (2010), who reported ADGs ranging between $190 \mathrm{~g} /$ day and $250 \mathrm{~g} /$ day. Average daily gain of $F_{1}$ crossbred lambs did not differ significantly $(P>0.05)$ from that recorded in the purebred DO and TA (188.9 g/day, $197.6 \mathrm{~kg} /$ day and 185.2 $\mathrm{kg} /$ day, respectively). During the entire suckling period (0 - 90 days of age), the DO and $R_{1}$ lambs had similar ADG values of $219 \mathrm{~g} /$ day $(P>0.05)$, which was significantly higher than the ADG of the other two genotypes $(P<0.001)$. The ADG values of all the three genotypes with DO genes were considerably higher $(P<0.001)$ than those in purebred TA lambs. These results are in agreement with those presented by MaciasCruz et al. (2009), who stated that Dorper sires improve reproductive efficiency and pre-weaning traits when crossed with Pelibuey ewes. Higher growth rates of lambs are desirable because of the evident benefits they can bring for the industry, such as lower weaning age, higher survival rates and higher body weight when marketed.

Litter size at lambing is linked directly to ovulation rate, thus selection for this trait would not be sufficient to increase lamb production (Vatankhah \& Talebi, 2008). Lamb survival rates and lambs' weight at weaning have to be considered when rearing sheep for mutton production, especially if crossbreeding is used, and exotic newly introduced breeds are used in this process.

In the current trial, the lamb survival rate was not affected by the genotype $(P>0.05)$. These results are in agreement with those of Schoeman \& Burger (1992) under South African farming conditions. The DO lambs recorded a survival rate of $94 \%$ to weaning, while in the current experimental conditions, purebred DO lambs recorded 93.7\% survival rate until weaning. According to Freaking \& Leymaster (2004), dam breed $(P=0.37)$ does not influence lamb survival to weaning, while sire breed does $(P<0.05)$. Results obtained in these trials concerning survival rates of the lambs are encouraging, and recommendations could be made to Romanian sheep farmers so that they can take advantage of DO meat production traits, alongside other specialised mutton breeds recommended by Pascal et al. (2010), such as Texel and Suffolk.

Increasing the level and efficiency of lamb production is of interest to commercial sheep producers because of the growing incomes from lamb sales (Snowder, 2002). Dorper ewes, born at the R\&D station or imported, manifested more intense oestrous periods in autumn, with $94 \%$ of them manifesting oestrous 
within 55 days. These results are similar to those of Romanian native breeds such as Turcana, Tigaia and Transylvanian Merino, with $94 \%$ - 98\% of the ewes manifesting oestrus cycles during the natural breeding season in a period of 45 - 50 days (Padeanu, 2011). Although ewes cycled in spring and summer, the cycling periods were much too irregular during these seasons. Producers normally plan for a more focused mating period, which will facilitate three lambings in two years. Focused mating allows for lambs of similar age and body weight and for better financial returns: for example more effective veterinary treatments in the same period; less time consuming; better prices from the slaughterhouse; and focused-feeding strategies. Thus, a reproduction trial outside the natural breeding season was considered, using melatonin implants for the grouping and inducing oestrus in both DO and TA ewes. The effects of melatonin implants on the out-ofseason reproductive performance in the DO and TA ewes are set out in Table 5.

Melatonin-treated DO ewes recorded significantly higher fertility rates than the control DO $(P<0.001)$ ewes, namely $88 \%$ and $41.6 \%$, respectively. For the TA genotype, melatonin treatment played an important role in the onset of fertility outside the breeding season, with the treated ewes recording a $50 \%$ fertility rate and the non-treated ewes only 14.2\% $(P<0.01)$. Differences between the two genotypes (DO vs. TA) were significant, when comparing the treated $(88 \%$ vs. $50 \% ; P<0.01)$ and non-treated ewes $(41.6 \%$ vs. $14.2 \%$; $P$ $<0.05)$. In both cases, the fertility of the DO ewes was higher than in the TA ewes. Results are in accordance with those of Wildeus (1997), who reported that although hair sheep are seasonal breeders, they tend to perform better under accelerated lambing systems, registering higher fertility and prolificacy rates than the traditional wool breeds.

In general, litter size was not significantly $(P>0.05)$ affected by the melatonin treatment in both genotypes, although a slightly higher prolificacy rate was observed for the melatonin-treated group compared with the non-treated group (127.2\% vs. $120 \%$ for the DO ewes, and $118.1 \%$ vs. $100 \%$ for the TA ewes). The current results regarding the performance of TA ewes outside the breeding season are in agreement with the findings of Padeanu et al. (2011), who reported a 14\% increase in the litter size of TA ewes when treated with melatonin implants during the autumn breeding season.

Table 5 Means $( \pm$ SEM) for reproductive performance of Dorper and Turcana ewes treated with melatonin outside the natural breeding season

\begin{tabular}{lccc}
\hline Genotype & $\mathrm{n}$ & Fertility (\%) & Litter size (\%) \\
\hline Dorper ewes implanted with melatonin & 25 & $88.0^{\mathrm{a}} \pm 8.46$ & $127.2^{\mathrm{a}} \pm 9.95$ \\
Control group I - Dorper ewes & 24 & $41.6^{\mathrm{b}} \pm 8.63$ & $120.0^{\mathrm{a}} \pm 14.77$ \\
Turcana ewes implanted with melatonin & 22 & $50.0^{\mathrm{c}} \pm 9.02$ & $118.1^{\mathrm{a}} \pm 14.08$ \\
Control group II - Turcana ewes & 35 & $14.2^{\mathrm{d}} \pm 7.15$ & $100.0^{\mathrm{a}} \pm 20.88$
\end{tabular}

${ }_{\text {a,b,c,d }}$ Column means with the different superscripts differ significantly at $P \leq 0.05$.

Schoeman \& Burger (1992) reported that in an accelerated mating system with 1.5 lambings per year, Dorper ewes recorded fertility rates of $85 \%$, with a litter size of $141 \%$. These results are similar to those found in the current trial, where the fertility was higher, but prolificacy was lower, possibly because among the DO ewes, one third was secundiparous. According to Gates (1993), in sheep the highest prolificacy is usually reached at the age of four years, which usually corresponds with the third or fourth lambing period, depending on the age at which the female is first introduced to ram. Similar results were reported by Hagger (2002), who stated that litter size increased considerably from first to second litter and slightly less, from second to third litter in studies carried out on four Swiss native breeds.

\section{Conclusions}

The DO breed and its crossbreds with the Turcana breed recorded better growth rates, an improved reproduction performances and increased early maturity for meat production. The DO breed performed well under Romanian semi-intensive management conditions, proving to be an adaptable breed to new rearing 
conditions. Thus Romanian sheep farmers should be encouraged to use the breed for stud breeding or for crossbreeding with the Turcana and other native dual-purpose breeds.

\section{Acknowledgements}

This work was published during the project "Postdoctoral School of Agriculture and Veterinary Medicine", POSDRU /89 /1.5 /S /62371, co-financed by the European Social Fund through the Sectorial Operational Programme for the Human Resources Development 2007-2013.

This work was partially supported by the Romanian Ministry of Education and Research throughout CNCSIS- UEFISCDI, project number 1091/2009 PNII - IDEI, code 2389/2008.

\section{References}

Baker, R.L., Steine, T.A., Vabeno, A.W., Bekken, A. \& Gjedrem, T., 1978. Effect of mating ewe lambs on lifetime productive performance. Acta Agric. Scand. 28, 203-207.

Brand, T.S., 2000. Grazing behaviour and diet selection by Dorper sheep. Small Rumin. Res. 36, 147-158.

Cloete, S.W.P., Snyman, M.A. \& Herselman, M.J., 2000. Productive performance of Dorper sheep. Small Rumin. Res. 36, 119-135.

Daraban, S., Coroian, C. \& Georgescu, B., 2009. Cluj Merino breeds’ potential for meat production. ABAH Bioflux. 1, 57-62.

Daraban, S., Georgescu, B., Padeanu, I., Voia, S., Pascal, C. \& Calin, I., 2011. Morpho-productive characterization of white Turcana breed population bred in Transilvania. Anim. Sci. Biotechnol. 44 (2), 370-375.

De Waal, H.O. \& Combrinck, W.J., 2000. The development of the Dorper, its nutrition, and a perspective of the grazing ruminant on veld. Small Rumin. Res. 36, 103-117.

Euro Stat, 2012. website: http:// epp. eurostat. ec.europa. eu/ portal/ page/portal/agriculture/data/ main _ tables (Report for the year 2011).

Fourie, P.J., Vos, P.J.A. \& Abiola, S.S., 2009. The influence of supplementary light on Dorper lambs fed intensively. S. Afr. J. Anim. Sci. 39, 211-214.

Freaking, B.A. \& Leymaster, K.A., 2004. Evaluation of Dorset, Finn sheep, Romanov, Texel and Montadale breeds of sheep: IV. Survival, growth and carcass traits of $F_{1}$ lambs. J. Anim. Sci. 82, 3144-3153.

Gaskins, C.T., Snowder, G.D., Westman, M.K. \& Evans, M., 2005. Influence of body weight, age and weight gain on fertility and prolificacy in four breeds of ewe lambs. J. Anim. Sci. 83, 1680-1689.

Gates, P.J., 1993. Non-genetic and breed variation in litter size in the Swedish sheep recording program. Acta Agric. Scand., Section A - Anim. Sci. 43 (3), 144-150.

Gavojdian, D., Padeanu, I., Voia, S. \& Bratu, I., 2010. Study regarding body weight of yearlings and mature indigenous sheep breeds reared in the Western part of Romania. Anim. Sci. Biotechnol. 43, 303-305.

Gavojdian, D., Sauer, M., Pacala, N., Padeanu, I. \& Voia, S., 2011. Improving growth rates in Turcana indigenous sheep breed using German Blackheaded Mutton rams. Anim. Sci. Biotechnol. 44(2), 379-382.

Georgescu, G., Banu, C., Croitoru, C., Savu, C., Tafta, V., Van, I., Lungu, S. \& Movileanu, G., 2000. Meat production and processing. Ceres Publ., Bucuresti, Romania. pp. 110-112. (in Romanian).

Hagger, C., 2002. Multitrait and repeatability estimates of random effects on litter size in sheep. Anim. Sci. 74, 209-216.

Ilisiu, E., Daraban, S., Neascu, G., Ilisiu, V. \& Rahman, G., 2010. Improvement of lamb production in Romania by crossbreeding of local Tsigai breed with high performance breeds. Landbauforschung vTI Agric. For. Res. 60, 259-266.

MADR (Romanian Ministry of Agriculture and Rural Development), 2012, website: http:// www.madr.ro /pages /page.php $=015 \&$ sub $=01501 \& t z=0150103$ - Report for the year 2011 (in Romanian).

Macias-Cruz, U., Alvarez-Valenzuela, F.D., Correa-Calderon, A., Molina-Ramirez, L., Gonzalez-Reyna, A., Soto-Navarro, S. \& Avendano-Reyes, L., 2009. Pelibuey ewe productivity and subsequent preweaning lamb performance using hair-sheep breeds under a confinement system. J. Appl. Anim. Res. 36, 255-260.

Milne, C., 2000. The history of the Dorper sheep. Small Rumin. Res. 36, 99-102. 
Nkosi, B.D. \& Meeske, R., 2010. Effects of whey and molasses as silage additives on potato hash silage quality and growth performance of lambs. S. Afr. J. Anim. Sci. 40, 229-237.

Notter, D.R., Greiner, S.P. \& Wahlberg, M.L., 2004. Growth and carcass characteristics of lambs sired by Dorper and Dorset rams. J. Anim. Sci. 82, 1323-1328.

Pacala, N., 1998. Embryo transfer in mammals. Helicon Publ., Timisoara, Romania. pp. 119-121 (in Romanian).

Padeanu, I., 2010. Meat production in sheep. Mirton Publ., Timisoara, Romania. pp. 3-5 (in Romanian).

Padeanu, I., 2011. Reproduction biotechnologies in sheep. Mirton Publ., Timisoara, Romania. pp. 12 (in Romanian)

Padeanu, I., Voia, S., Gavojdian, D., Fratila, I., Mircu, C., Bratu, I, Pascal, C. \& Sauer, W.I., 2011. Effects of using melatonin implants on reproductive performances in Turcana ewes. Anim. Sci. Biotechnol. 44, 387-389.

Pascal, C., Gilca, I., Ivancia, M. \& Nacu, G., 2010. Researches related to fattening performances achieved by hybrids issued from Romanian sheep breeds crossed with meat type rams. $61^{\text {st }}$ Annual meeting of the EAAP, Heraklion, 23-27 August, Crete Island, Greece, Session 35 - Communications in sheep and goats production. pp. 1-5.

Ramsey, W.S., Hatfield, P.G., Wallace, J.D. \& Southward, G.M., 1994. Relationship among ewe milk production and ewe and lamb forage intake in Targhee ewes nursing single or twin lambs. J. Anim. Sci. 72, 811-816.

Sauer, M., Sauer, W.I. \& Gavojdian, D., 2011. Reproductive performance of $\mathrm{F}_{1}$ Lacaune x Turcana primiparous ewes. Food Safety Prod. J. Treb. 1, 84-87.

Schoeman, S.J., 2000. A comparative assessment of Dorper sheep in different production environments and systems. Small Rumin. Res. 36, 137-146.

Schoeman, S.J. \& Burger, R., 1992. Performance of Dorper sheep under an accelerated lambing system. Small Rumin. Res. 9, 265.

Snowder, G.D., 2002. Composite trait selection for improving lamb production. Sheep Goat Res. 17, 42-49.

Snowder, G.D. \& Duckett, S.K., 2003. Evaluation of the South African Dorper as a terminal sire breed for growth, carcass, and palatability characteristics. J. Anim. Sci. 81, 368-375.

Snyman, M.A. \& Herselman, M.J., 2005. Comparison of productive and reproductive efficiency of Afrino, Dorper and Merino sheep in the False Upper Karoo. S. Afr. J. Anim. Sci. 35, 98-108.

Vatankhah, M. \& Talebi, M.A., 2008. Heritability estimates and correlations between production and reproductive traits in Lori-Bakhtiari sheep in Iran. S. Afr. J. Anim. Sci. 38, 110-118.

Voia, S., 2005. Sheep and goats practical breeding guide, Waldpress Publ., Timisoara, Romania. pp. 68-70 (in Romanian).

Wildeus, S., 1997. Hair sheep genetic resources and their contribution to diversified small ruminant production in the United States. J. Anim. Sci. 75, 630-640. 